\title{
A Depiction of Gender Role in the Movie of Incredibles 2 (2018)
}

\author{
Raihan Nurul Fahira ${ }^{1}$, Ririn Kurnia Trisnawati ${ }^{2}$, and and Muhammad Taufiqurrohman ${ }^{3}$ \\ Jenderal Soedirman University ${ }^{1}$, Purwokerto, rnfahira@yahoo.co.id \\ Jenderal Soedirman University ${ }^{2}$, Purwokerto, trisnawati2001@yahoo.com \\ Jenderal Soedirman University ${ }^{3}$, Purwokerto, muhammad.taufiqurrohman@ unsoed.ac.id
}

\begin{abstract}
The research aims to figure out the gender roles which are used to look at how the film constructs and upholds gender roles. The qualitative method is used to analyze the data in which the primary data are taken from Brad Bird's Incredibles 2 (2018). Additionally, the researcher used gender roles and cinematography theory to look at how gender is a performance and also to gain a result that gender roles are changing overtimes. The use of Judith Butler's theory of performativity is to show that the portrayal of gender roles in the movie is slightly different from social construction. There were eleven data in the form of sentences which contained gender roles used by male and female performance. The data were classified by the two genders, they are male and female. The result showed that Butler's notion of performativity refers to an act of performance that an individual is doing repeatedly as described in Incredibles 2 where Bob and Helen do the gender role reversal and share the same responsibilities in the family. Bob is previously shown as the breadwinner of the family and the main earner while Helen is a full-time stay-at-home mother who takes care of the children and the house. Since they no longer hold the traditional gender role; therefore, the movie demonstrates how they start to swap gender assigned tasks. Accordingly, the gender roles are showcased as Bob is being the househusband and the caretaker of the family while Helen is a working woman.
\end{abstract}

Keywords: Incredibles 2, Gender Role, Cinematography, Performativity Theory by Judith Butler

\section{INTRODUCTION}

Historically, the terms sex and gender have been used interchangeably, but their uses are becoming increasingly distinct (Newman, 2018), and it is a common misconception that the words gender and sex are used to describe the same thing. Both of them are quite different. Sex is generally our biological status. It reflects and indicates our physiological and biological characteristics -those characteristics that cannot change from one society to another or from time to another. Meanwhile, gender is what our community asks us what to do, think, or behave. It attributes to characteristics that can change from one society to another or throughout time.

Gender roles describe what you have to do and what you do not have to do and this idea is socially constructed by the society itself. Instead of talking about body parts, it is more about how we are expected to act due to our sex. Some roles have been assigned to men and women due to their sex, for instance, men are the breadwinner and the dominant figure of the family. On the other hand, women are the stay-at-home parent whose main duty is being the primary caregiver of the family. Moreover, women cannot be part of decision-makers in a family because of society standards stipulate that only men are entitled to 
make choices in a family. Here, we can see that gender is about determining one's masculinity and femininity. Masculinity creates a society of clearly distinct gender roles, where men should be "assertive, tough, and focused on material success," while women should be more "modest, tender, and concerned with the quality of life" (Hostede, 2001, p. 297). That is to say, society has a big impact on gender because they have created a set of social expectations that define the behaviors that are appropriate for men and women and determine women's and men's different access to rights, resources, power in society and health behaviors (Galdas, P. M.; Johnson, J. L.; Percy, M.E.; Ratner, P.A, 2010). However, gender expectations in some cultures can differ from one culture to another, depending on how people perceive gender roles.

The changing of gender roles is presented in the sequel of The Incredibles (2004), namely Incredibles 2 (2018). Differing from the first film where Bob Parr worked as a white-collar job while Helen Parr stayed at home to raise the kids - in this sequel, Helen worked to fight the villains and Bob needed to look after the children. The film challenged gender stereotypes and how they proved to the audience that it changes over time and did not stay the same. In this film, Bob and Helen flip the traditional family dynamics. Incredibles 2 (2018) illustrates that this film recognizes historical problems with sexist roles and gender norms and the film actively changes people's perception of gender roles.

This research employs Judith Butler's gender performativity, using one of her major works entitled Gender Trouble: Feminism and the Subversion of Identity (1990), in which she challenges conventional notions of gender and develops her theory of gender performativity. Butler states that gender is performative. Gender, "is real only to the extent that it is performed" (Butler, 1988, p. 527). In Gender Trouble (1990), Butler seeks to criticize what she considers to be an outdated gender perception. This outdated perception is limited because it obeys to the dominant social boundaries that refer to gender as binary. In researching gender, Butler introduced her point of view which results in the united concepts of performativity and gender. Butler considers gender to be built through a series of actions that are said to be in accordance with dominant social norms.

There are several previous studies on gender roles. The first study is from Janice Natasha who wrote her thesis entitled Penerimaan Suami dan Istri Mengenai Gender Role Dalam Rumah Tangga Melalui Tayangan Sitkom Tetangga Masa Gitu (2016). It tells about the relying husband on his working wife while he is a stay-at-home husband. By looking at the first previous study, it is relevant to the issue of Incredibles 2 (2018) which represents gender equality in the marriage. The second study is from Katriza Andika Putri entitled The Changes of Women's Image Represented by Snow White Character in Mirror Mirror Movie (2013). The study uncovers Snow White's experience in the changing of gender roles and the image of a woman. Women in the movie Mirror Mirror (2012) are no longer described as a weak human being. They are now portrayed as a strong and brave character. The female character in the movie is able to fix her own problem. The third and final study is from Ridwan entitled Male Gender Role Pada Karakter Superhero Dalam Film Produksi Marvel Studios (2014). The writer tried to find out which male gender role that exists in the Marvel studios. This study is also related to the issue of Incredibles 
2 (2018) due to the description of men in traditional society are as the breadwinner. Yet, men are no longer illustrated as the breadwinner since women can also work and support their families.

This research attempts to figure out the gender roles and how the movie completely breaks the stereotype. Seeing the ever-changing debate about gender roles over the years, it is clear to see in today's society; both men and women are an equal partnership. Moreover, this research focuses on how gender roles are well illustrated in the movie of Incredibles 2 (2018) as the object of this research. In order to gain a result that gender roles are changing, the researcher uses Butler's notion of gender performativity to look at how husbands and wives can reverse the roles.

\section{LITERATURE REVIEW}

This research employs Judith Butler's gender performativity, using one of her major works entitled Gender Trouble: Feminism and the Subversion of Identity (1990), in which she challenges conventional notions of gender and develops her theory of gender performativity. Butler states that gender is performative. Gender, "is real only to the extent that it is performed" (Butler, 1988, p. 527). In Gender Trouble (1990), Butler seeks to criticize what she considers to be an outdated gender perception. This outdated perception is limited because it obeys to the dominant social boundaries that refer to gender as binary.

The essence of Butler's argument in Gender Trouble (1990) is the coherence of sex, gender, and sexuality - is constructed through the repetition of actions. According to Butler's point of view, gender is built through repetitive actions linked to men or women. Currently, the actions appropriate for men and women have been transmitted to produce a social atmosphere that both maintains and legitimizes a seemingly natural gender binary (Butler, 1988, p. 519-531).

Since gender is a performative and refers to an act of performance that an individual is doing repeatedly, Bob and Helen perform their gender role throughout the film. Bob used to be the breadwinner and the number one man, but since the film breaks the gender stereotype, men are no longer seen to be the dominant figure. Also, women now can enter the workforce and become leaders while men can actively participate more in their children's lives. Married couples tend to leave traditional gender roles behind and start being cooperative with each other by sharing the same number of tasks.

\section{METHOD}

The data are collected from Incredibles 2 (2018) by Brad Bird. There are eleven data analysed in this study. Firstly, in order to obtain the data, intense watching is conducted more than seven times. The intense re-watching provide a deeper understanding about of gender roles in the movie. Second, the data taken from the film which are in the forms of dialogues, actions, character's depictions and thoughts and also the cinematography elements are classified into female and male performance. Third, the data which are taken from other sources, such as books, journals, articles, and other references related to the research are used to support the analysis. Fourth, in displaying the data from the movie, the data is based on the theory of gender role and cinematography. 
The next, in reducing the data, the researcher takes the data that is relevant to the research. In analyzing the data, Butler's theory of gender performativity is used to analyze the gender role itself. In validating the data, the researcher tries to search as many sources as possible that are related to the research. In concluding the data, the researcher must have answered the research question.

\section{FINDINGS AND DISCUSSIONS}

The purpose of this study is to show the readers that the portrayal of gender roles in the movie is slightly different from the common social construction. As previously explained, the gender role in the Incredibles 2 (2018) is based on Judith Butler's theory of performativity, argued within her major book entitled Gender Trouble: Feminism and the Subversion of Identity (1990). Butler argues that gender is a series of actions and both men and women always perform their gender in everyday life. Since Bob and Helen perform their gender role reversal, thus, this discussion is divided into two: male performance and female performance.

\section{Male Performance}

The researchers found five data relating to the male performance. In the process of presenting the data, the researcher only took some as the representative data for the needs of analysis.

Today, married couples establish the modern view that both men and women are an equal partnership. Here, in this first part of male performance, the performance is observed based on Bob's role as a househusband and his main role as a househusband in the movie is being as a supportive and domesticated husband that will be explained further below.

\section{Supportive Husband}

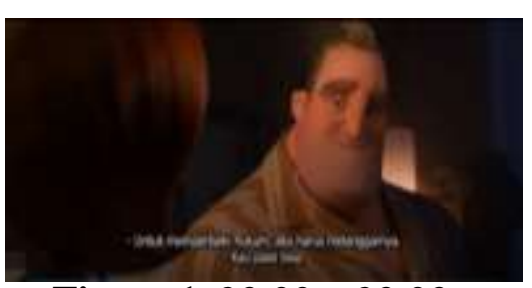

Figure 1. 23:00 - 23:03

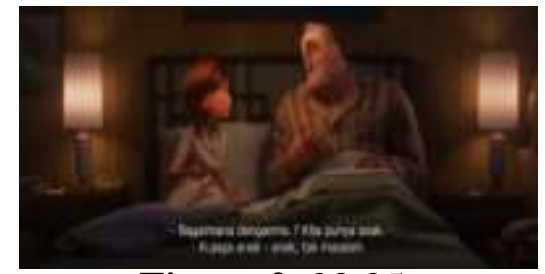

Figure 2. 23:05

In this state, Bob showed his supportive attitude by convincing her to accept the job, while Bob looked after the house and the children. Even if at first he gets jealous of his wife's achievement, he gradually learns that family comes first, so he gives his support to his wife. As the narrative progresses, they learn to swap gender-assigned tasks.

Based on this circumstance, the modern social structure sees both men and women as equal partners of society with equal rights, status, and responsibility. Moreover, in today's society, the roles in marriage are less strict 
and do not stick to the conventional ways. Today, the married couple has more freedom to choose which everyday tasks they wish to do.

2. Domesticated Husband

2.1 Being a Caretaker

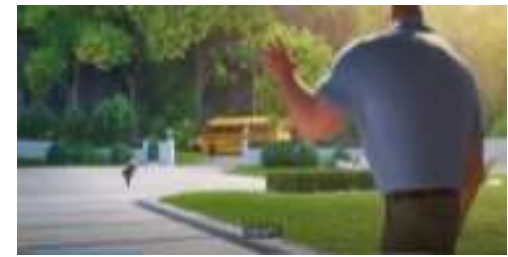

Figure 3. 27:08-27:40

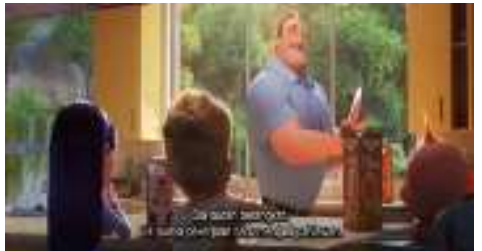

Figure 4. 27:45-27:55

According to Carroll (2016), for several decades, a social movement has quietly grown as we re-examine gender roles, expand the definition of family and redefine what it means to be masculine. As reflected in the movie, the trend is starting to shift and most fathers now are actively engaged in every possible way.

Some men who choose this role may do so because they enjoy being an active part of their children's lives, while in other families, the mother wants to pursue her career (Gill, 2001). Bob is shown to be willingly doing it in the first place because he wants his wife to be happy. He allows his wife to work without having to use daycare or a housemaid. As a result, his wife is free from the stress of childcare, and she can actively pursue her career.

\subsection{Bob Encountering Difficulties}

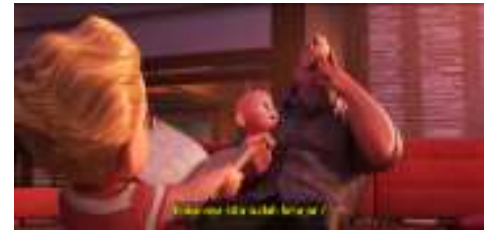

Figure 5. 1:02:03 - 1:02:20

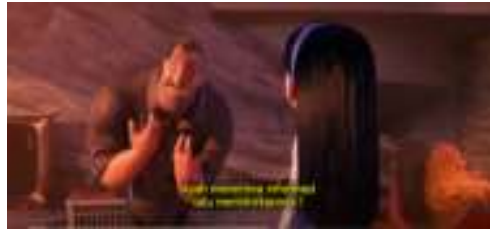

Figure 6. 1:03:55 - 1:04:40

The pictures above indicate Bob being discouraged and faced some hardships during his role as a househusband. With so many duties he should do, Bob is the same as a housewife in general. Bob's confusion at the beginning has an impact on his performance at home while caring for his children, which makes the audience jump into a conclusion that Bob always depends on his wife in the first film. That is why when they reverse the roles; Bob is confused about his role as a father.

At first, Bob had a deep sense of accomplishment in successfully maintaining his new role as a primary parent. Nevertheless, as nights go by, he shows signs of breaking down. According to Butler, gender is not an underlying essence or nature of which gendered behavior is the product; it is a series of acts whose constant repetition creates the illusion that an underlying nature exists (Brian, 2020). Since doing gender role is a series of actions that carried out by an 
individual - therefore, when Bob does gender role that is too repetitive and never done this before, he begins to be overwhelmed and shows how exhausted it is to be a father who handles everything himself.

\section{Female Performance}

Different from the male performance showing five data, the female performance is shown in six data. But the same as male performance in ways of presenting the representative data. This section also presented the representative data to be analysed below.

Women are finally getting their place in the workforce and the company began to appreciate women's competence in the working world. Whilst the first film focuses almost entirely on Bob, he struggles to let his wife shine in the spotlight. Now, Helen is at the forefront being the heroine in this film. In fact, she deserves more spotlights in the first place. Her decision brings her certain consequences that she has to leave her family, stay separately in a hotel from her family, and be an oncall heroine from morning until night. This data coincide with the study conducted by Rosarini, Paturrohmah, and Assiddiqi (2020) that the aspect of masculinity as the image of heroine in a literary work believed as someone who has special competence and makes the readers believe that the women character has masculinity. Here, the performance is observed based on Helen's role as a heroine figure and also as a working woman.

\section{Heroine Figure}

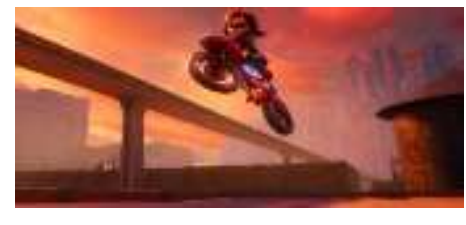

Figure 7. 32:25-33:10

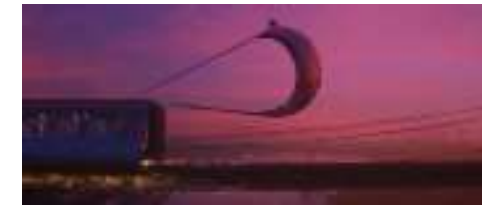

Figure 8. 34:12

The above pictures portray Helen's role as a heroine figure who works her best to save many people in the Hovertrain. In carrying out her work as a hero who is known and idolized by the public, Helen shows her performance as a female hero which signifies that women also have the same quality and excess as men. In this matter, Helen's role as a heroine shows the audience that women have many abilities that have not been admitted by anyone, even her own husband.

Through Helen's being a heroine in this film, the superhero character does not need to only glorify men, but women also have those kinds of power. As a result, the role of women has changed utterly in our society today. 


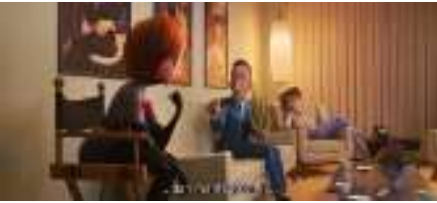

Figure 9. 43:54

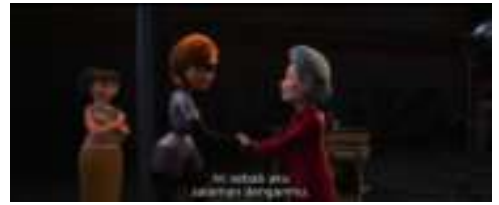

Figure 10. 44:14

With the achievement of gender equality, women now can enter the workforce and build as many relationships as possible with their coworkers and have the same position as men. By putting forward an opportunity for Helen to do impactful work and complete it successfully, the film encourages the inclusion of women in the workplace and portrays it as positive progress. As opposed to the first film, Helen now thrives in her independence and is in the spotlight until the very end of the film. Women now finally gain their position in the workforce, as displayed in this film; Helen manages to prove to herself, the society, and also to her husband that she is his professional equal. This seems to say that, when allowed, women can perform at an equal standard in the workplace and they are highly capable of exceeding expectations (Summersgill, 2018).

\section{CONCLUSIONS}

conclude, Incredibles 2 (2018) no longer applies the traditional gender role system, but rather illustrates the state of married life in the modern era where women today have the opportunity to work and have the same rights as men in general while it is acceptable for men to be the primary caregiver of the family. The gender role depiction of the characters in this film is examined through their gender performances. The gender performance can be explicitly seen through Helen and Bob's performance. Helen, who was a housewife and a part-time heroine, now has full access being a working woman. On the other hand, Bob, who used to be a breadwinner of the family and worked full time as a superhero, is now a stay-at-home father with his children. Through this gender role, both men and women have responsibilities that can be shared and carried out equally.

\section{REFERENCES}

\section{Journal Article}

Butler, Judith. (1988). Performative Acts and Gender Constitution: An Essay in Phenomenology and Feminist Theory. Theatre Journal. 40 (4): 519-531.

Galdas, P. M.; Johnson, J. L.; Percy, M.E.; Ratner, P.A. (2010). Help seeking for cardiac symptoms: Beyond the masculine-feminine binary. Social Science \& Medicine. 71 (1): 18-24.

Ridwan. (2014). Male Gender Role Pada Karakter Superhero Dalam Film Produksi Marvel Studios. Jurnal E-Komunikasi. Vol 2 No. 3 Tahun 2014. Universitas Kristen Petra, Surabaya.

Rosarini, I., Paturohmah, P., \& Assiddiqi, H. 2020. Masculinity of heroine in Xena: warrior princess and the hunger games (2012). Call Journal, Vol 2(1), 46-55. 


\section{Internet Website}

Brian, Duignan. (2020). Judith Butler. Britannica: February 20, 2020. https://www.britannica.com/biography/Judith-Butler

Carroll, Charles. (2016). Fathers as Caregivers. The New York Times: July 23, 2016.

Newman, Tim. (2018). Sex and gender: What is the difference? Medically reviewed by Karen Cross, FNP, MSN on February 7, 2018.

https://www.medicalnewstoday.com/articles/232363\#gender-differences

Summersgill, Tamina. (2018). Stretching the gender roles: The Incredibles' Elastigirl setting an example as the working woman. Palatinate: October 7, 2018. https://www.palatinate.org.uk/stretching-the-gender-roles-the-incredibleselastigirl-setting-an-example-as-the-working-woman/

\section{Book}

Butler, Judith. (1990). Gender Trouble: Feminism and the Subversion of Idenity. $1^{\text {st }}$ ed. Linda Nicholson. New York: Routledge.

\section{References}

Gill, Libby. (2001). Stay-At-Home Dads: The Essential Guide to Creating the New Family. New York: Penguin Group.

Hofstede, G. (2001). Culture's Consequences. $2^{\text {nd }}$ ed. p. 297.

Natasha, Janice. (2016). Penerimaan Suami dan Istri Mengenai Gender Role Dalam Rumah Tangga Melalui Sitkom Tetangga Masa Gitu. Universitas Katolik Widya Mandala, Surabaya.

Putri, Andika Katriza. (2013). The Changes of Women's Image Represented by Snow White Character in Mirror Mirror Movie. Department of Languages and Literature. Universitas Brawijaya. 